\title{
RUŠTí SPISOVATELÉ O UMĚNÍ PŘEKLADU
}

\author{
STANISLAV RUBÁŠ
}

\begin{abstract}
Russian Writers on the Art of Translation

The paper elaborates on a selection of canonical texts by Mikhail Lomonosov (1711-1765), Alexander Pushkin (1799-1837), and Vladimir Nabokov (1899-1977), reflecting on the art of literary translation. A thorough analysis of these writings, covering the period from the mid-18 century to the mid- 20 century, reveals a striking continuity of thought, especially in terms of the Russian writers' perception of their mother tongue and of poetry as the national language's subtlest manifestation. All the texts analysed are, more than anything else, marked by the Muse of poetry, a key feature defining Russian national mentality.
\end{abstract}

Keywords: the art of literary translation; Lomonosov; Pushkin; Nabokov

Když zkraje šedesátých let v Sovětském svazu vyšla antologie Ruští spisovatelé o překla$d u$ (Fjodorov - Levin 1960), museli být nejen její laičtí, ale i mnozí zasvěcení čtenáři překvapeni, kolik myslitelské práce klasikové ruské literatury věnovali otázkám uměleckého překladatelství. Antologie přitom zdaleka neobsahovala pouze úvahy o „technice“ překladatelské práce, ale rovněž o ruském jazyce a národnosti, jakož i četné charakteristiky literárních děl, at už byla překládána $\mathrm{z}$ cizích jazyků (zejména $\mathrm{z}$ francouzštiny, němčiny a angličtiny) do ruštiny, nebo naopak.

Editor knihy Andrej Fjodorov (1906-1997) v jejím úvodu konstatuje, že „cenné dědictví v oblasti teorie překladu, které po sobě zanechali ruští spisovatelé, dosud nebylo náležitě prozkoumáno ani zpopularizováno“ (Fjodorov 1960: 3f). Bezmála sedmisetstránková publikace, kterou Fjodorov společně s dalšími čtrnácti kolegy sestavil z desítek kritických statí, dopisů, deníkových záznamů i úryvků literárních děl, se tak v ruských dějinách překladu stala prací zakladatelskou a nadlouho i jedinou svého druhu. ${ }^{1}$

Na ruskojazyčnou antologii, pokrývající období od třicátých let 18. století do třicátých let 20. století, jmenovitě od Antiocha Dmitrijeviče Kantěmira (1709-1744) po Maxima Gorkého (1868-1936), navázali v 21. století rusisté působící ve Spojených státech Brian James Baer a Natalia Olshanskaya (2013). Jejich anglojazyčný soubor sice nedo-

1 První obdobnou antologii představuje druhý díl knihy České teorie překladu vydané v roce 1957 českým teoretikem překladu Jiřím Levým. 
sahuje ani třetinového rozsahu své sovětské předlohy, avšak na rozdíl od ní zahrnuje rovněž texty Mariny Cvetajevové (1892-1941), Varlama Šalamova (1907-1982), Natalie Gorbaněvské (1936-2013) a mnoha dalších, jejichž tvorba byla v Sovětském svazu po většinu jejich tvůrčího života vykázána na okraj zájmu, nebo přímo zakázána. Americká antologie se tak dotýká otázek, které sovětští badatelé směli z ideologických důvodů pojednat výhradně v souvislosti s carským Ruskem. Zevrubně je tu zpracována sovětská překladová cenzura, překlad jako forma vzdoru sovětského občana a v neposlední řadě překlad vězeňský, totiž tajná činnost př̀ekladatelů sovětskou justicí odsouzených k odnětí svobody v táborech Gulagu.

Nejnověji se podobnou cestou vydali badatelé Ústavu translatologie Filozofické fakulty Univerzity Karlovy, kteří (zčásti s přispěním svých studentů) ${ }^{2}$ vybrali a přeložili do češtiny osmadvacet reflexí devatenácti klasiků ruské literatury, počínaje Michailem Vasiljevičem Lomonosovem (1711-1765) a konče Josifem Brodským (1940-1996). ${ }^{3}$

\section{Rusko v zrcadle překladu}

V českojazyčné antologii, nazvané Rusko v zrcadle překladu, se potkávají ruští spisovatelé, aby - napříc třemi stoletími - vedli společnou řeč. O ruském jazyce i národnosti a především o umění překladu. Z textů, pocházejících z 18., 19. a 20. století (a s jednou výjimkou přeložených do češtiny vůbec poprvé, nebo nově), přitom vyvstává odpověd' na otázky dodnes aktuální: Co si Rusové v konfrontaci s cizími jazyky a kulturami uvědomují sami o sobě? Co vlastně dělá Rusa Rusem? A má ruský národ opravdu jakousi zvláštní „duši“?

Obraz Ruska v zrcadle překladu je pozoruhodně prokreslený, nebot překlad sám vše národně svébytné a jedinečné projasňuje i vyostřuje. A třebaže se úvahy ruských spisovatelů ohledně „ruské duše“ liší úhlem pohledu i tvůrčím typem jejich autora, jedno mají společné. Většina z vybraných esejů, veršů, dopisů a rozhovorů se dotýká poezie, té „rodné řeči “ básníků, která hranice každé mateř̌štiny i národnosti dalece přesahuje (Cvetajeva 1995: 66-67). Stejně jako umění překladu, spočívající nikoliv v lexikálních výměrech slov, nýbrž v interpretaci toho, co se skrývá za slovy.

Jak napsala Marina Cvetajevová v roce 1926: „Poezie sama je překladem, a to z rodné řeči do cizí - do francouzštiny, němčiny, na tom nesejde. Básníci nemají mateřštinu. Psát básně současně znamená je překládat“ (Cvetajeva 1995: 66). I ruská básnírka nicméně přiznává, že „v každém jazyce je něco pouze jemu vlastního, něco, co samo je tímto jazykem“ (Cvetajeva 1995: 66).

V této stati se pokusíme přiblížit jednu z otázek, které provázejí myšlení ruských spisovatelů o překladu takřka od jeho prapočátku - otázku po povaze a významu ruské řeči.

2 První, hrubé verze některých překladů vznikaly v rámci specializovaných překladatelských semináŕů Ústavu translatologie FF UK, které vedli editoři a překladatelé antologie Anna Rosová a autor tohoto článku.

3 Antologie zahrnuje texty M. V. Lomonosova, A. S. Puškina, I. S. Turgeněva, V. G. Bělinského, N. V. Gogola, V. A. Žukovského, N. G. Černyševského, F. M. Dostojevského, V. Brjusova, N. Gumiljova, M. Cvetajevové, O. Mandelštama, V. Nabokova, B. Pasternaka, B. Achmadulinové, S. Maršaka, K. Čukovského, A. Achmatovové a J. Brodského. 


\section{Jazyk ruský nejpřednější jest}

Takto zachytil svébytnost ruské řeči polyhistor Lomonosov v dedikačním listě ke své Gramatice ruské z roku 1755, ${ }^{4}$ adresovaném careviči Pavlovi (1754-1801) z dynastie Romanovců, prvorozenému synu Kateřiny Veliké:

Vládce jazyků mnoha, jazyk ruský, netoliko širokostí světa krajů, nad kterýmiž panuje, nýbrž i obšírností a hojností vlastní mezi všechněmi jazyky evropskými nejpřednější jest. [...] Karel Pátý, imperátor římský, děl, žet’ s Bohem po španělsku, s druhy svými po fransku, s protivníky po německu, s pohlavím ženským po vlašsku obcovati se patří. Kdyby však jazyka ruského byl znal, jistě by $\mathrm{k}$ tomu byl přidružil, že s těmi i oněmi po rusku hovořiti př́padné jest, neb shledal by v něm velikolepost jazyka hispánského, jiskru jazyka franského, pevnost jazyka německého, jemnocitnost jazyka vlašského, a nadto taktéž bohatství a jadrnost obrazné krátkosti řeči helénské a latinské. Doložiti gruntovně svrchu uvedené žádát si jiného místa i času. Mne docela v tom utvrzuje let mnohých cvik v řeči ruské. Mocná výmluvnost Ciceronova, velikolepá vážnost Vergiliova, libá krasořečnost Ovidiova netratí v jazyce ruském nižádné ze svých vnad. (Lomonosov 1952: 391-392)5

Máme před sebou klasickou ukázku obřadného vyjadřování učenců doby osvícenství. Slova vědce, který sepsal první rusky psaný výklad ruského pravopisu, jsou ovšem zcela „nevědecká“, přesněji - vědeckými prostředky nedokazatelná. Představují však, zejména část vycházející z údajného výroku císaře Svaté říše římské, jednu z Lomonosovových nejvlivnějších myšlenek, podepřených mnohaletým „cvikem v řeči ruské“, totiž vlastními překlady z Cicerona, Vergilia, Ovidia a dalších antických autorů. ${ }^{6}$

Imperiálně neochvějné jazykové sebevědomí, vyzařující z Lomonosovových slov, se časem stalo neodmyslitelnou součástí vztahu Rusů k jejich mateřštině - především díky básníkům a romanopiscům 19. století, kteří rusky psané literatuře jako první dali její světovost a $\mathrm{v}$ duchu Lomonosovovy rétoriky znovu a znovu zdůrazňovali výjimečnost ruské řeči.

Největší básník předpuškinovského Ruska Gavrila Romanovič Děržavin prohlásil v roce 1812, že „ruskoslovanská řeč [...] smělostí vyrovná se latině a ladností řečtině, převyšujíc všechny jazyky evropské: italštinu, francouzštinu i španělštinu, o němčině nemluvě“ (Deržavin 1872: 595). V roce 1825 dospěl k témuž závěru i samotný Alexandr Sergejevič Puškin, přesvědčený, že „jazyk ruskoslovanský coby matérie slovesnosti všechny evropské jazyky bezesporu předčí (Puškin 1954: 75), a v neposlední řadě rovněž Nikolaj Vasiljevič Gogol, hlásající v roce 1846, že ruština je „bohatší a dokonalejší než všechny jazyky evropské“ (Gogol 1952: 237). A ve výčtu podobných výroků bychom snadno mohli pokračovat dál.

Je přitom symbolické, že ten, kdo poprvé rusky zformuloval pravopisný systém i velmocenské postavení ruštiny v rodině evropských jazyků, byl zároveň otcem zakladatelem novodobé ruské literatury. Také Lomonosov byl básníkem. Kromě překladů antických

Dílo samotné bylo vydáno v roce 1757 s vročením 1755.

Není-li uvedeno jinak, citované texty přeložil autor stati.

6 Lomonosov překládal rovněž Homéra, Anakreonta, Juvenala, Démosthena, Lúkiana, Tacita, Horatia, Martiala, Seneku, Claudiana a Lucretia. 
veršů vytvořil nemálo děl, ze kterých vychází celá pozdější ruská poezie, pokud jde o básnický jazyk i formu.

Jestliže tedy na konci dedikace ke svému jazykovědnému spisu z roku 1755 Lomonosov (1952: 393) sám sebe označuje za „nejponíženějšího raba“ budoucího panovníka, jemuž byl v den slavnostního předání rukopisu právě jeden rok, jde především o rétorickou konvenci doby. V ruských duchovních dějinách je Lomonosovovo myšlenkové dědictví jedno z nejvlivnějších a nejvýznamnějších vůbec. Stalo se, řečeno spolu s Horatiem, kterého ruský vědec rovněž př̀kládal, „trvalejší kovu“.

\section{Překladatel jako zvěstovatel nového slova}

Autoritu a vliv Lomonosovových myšlenek si už stěží dovedeme představit. Zvláště dnes a zvláště my s naší českou historickou zkušeností s autoritami všeho druhu. Zůstaneme-li u autorit duchovních, náš vztah k nim často byl a je poznamenán jistou rezervovaností,7 zatímco Rusové svého Lomonosova, Puškina či Gogola vždy a většinově měli v jakési posvátné úctě - jako proroky přinášející nové slovo, novou zvěst.

Takto v roce 1832 oslovuje Puškin (1995: 481) svého druha v básnickém i překladatelském ${ }^{8}$ řemesle Nikolaje Ivanoviče Gnědiče, který dva roky předtím vydal nový ruský překlad Homérovy Iliady:

Mnoho let s Homérem jsi mluvil o samotě, než k synům svého plemene z tajemných vrcholků jsi v záři sešel poté, třímaje desky kamenné.

Nás dole v ležení jsi našel, v pláni holé, $\mathrm{v}$ marnivých hodech ztřeštěně jsme písně zpívali a tancovali kolem té modly námi vztyčené.

My odvrátili zrak, tvou září ohromeni.

A ty? Tys žalem oněměl?

Proklel jsi, proroku, ten lid svůj pomatený, roztř́ištiv desky kamenné?

$\mathrm{Ne}$, neproklel. Jsi z těch, kdo v nížinu rád chodí

a do stínu se pohrouží,

kdo zahřmění má rád za letní nepohody

i bzukot včely nad růží.

To pravý básník je. Tragickou lyrou Recka

Melpomené ho strhává,

leč pobaví ho pak i fraška prostořeká

7 Za všechny uved’me českého badatele Jana Evangelistu Purkyně (1787-1869), jehož dílo má ve vědeckém světě podobnou váhu jako dílo samotného Lomonosova. Na rozdíl od Lomonosova však Purkyně musel ze své vlasti odejít za živobytím do ciziny, na wrocławskou univerzitu, kde pak působil celých dvacet sedm let.

8 Např́iklad Puškinova poema „Angelo“ je básnickou adaptací Shakespearova dramatu Measure for Measure (česky nejnověji Něco za něco), která může být studována jako určitý vzor básnického přístupu k Shakespearovu jazyku. 
při jarmarečních zábavách,

zláká ho starý Řím i slavné trójské pláně,

Ossianovy útesy

a s božskou lehkostí se vydá za Ruslanem

po cestách starých pověstí.

Obraznost prvních dvanácti veršů vychází z 24. a 32. kapitoly biblické knihy Exodus. Puškin se k překladateli Iliady obrací jako k proroku, který sestoupil z horských výšin k svému lidu, aby mu přinesl „desky kamenné, totiž nový překlad starověkého eposu. Stejně tak se Mojžíš vrátil ze Sinaje k synům izraelským, aby jim předal kamenné desky, do nichž bylo božím písmem vyryto desatero přikázání. Avšak podobně jako synové izraelští, i lid ruský si už vytvořil novou „modlu“, ztřeštěně uctívanou starými písněmi a tanci. Mojžíš na znamení hněvu kamenné desky, dílo Hospodinovo, roztříští. Ruský překladatel Iliady se však nehněvá. Je přece jen více člověkem nežli prorokem. A hlavně je „pravým básníkem“, sestupujícím z „tajemných vrcholkư“ dolů, do nížiny, kvůli inspiraci.

Starozákonní patos i étos Puškinovy básně prozrazuje, jak mimořádnému postavení se překlad v Rusku těšil: „V celých moderních dějinách Ruska se o zdařilých překladech cizích literárních děl běžně mluvilo jako o ,událostech', ,svátcích“ či dokonce ,zázracích.“” (Baer - Olshanskaya 2013: 4f) Puškinovy verše však oslavou nekončí: ruský lid podle něho vzývá falešnou modlu, totiž to, co bylo v tehdejší literární Evropě zrovna v módě, jak shrnuje Puškin v roce 1830, necelý rok poté, co Gnědičova Illiada vyšla poprvé tiskem:

V době, kdy se valná většina spisovatelů, zhýčkaných chvilkovými úspěchy, vrhla na tvorbu formálně oslnivých cetek, kdy se talent vyhýbá práci a móda opovrhuje vzory vznešeného dávnověku, kdy poezie už není pokornou službou, nýbrž jen lehkovážnou kratochvílí, v této době s pocitem hluboké úcty a vděku hledíme na básníka, který hrdě zasvětil nejlepší roky života mimořádnému úkolu, nezištné inspiraci a zcela ojedinělému, velkému činu. Držíme v rukou ruskou Iliadu [...], která musí podstatným zpo̊sobem ovlivnit naši literaturu. (Puškin 1960: 159-160)

Puškinův obdiv vůči Gnědičovi a jeho Homérovi namnoze sdílel také první mezi ruskými kritiky 19. století Vissarion Grigorjevič Bělinskij. Na základě četby uvedeného překladu prohlásil, že ruština je „jedním z nejštastnějších jazyků, pokud jde o schopnost tlumočit díla starověku“ (Belinskij 1960: 224). Jednu z jejích nejhlubších vrstev, kterou Gnědič v převodu Homérových veršů bohatě využil, totiž tvoří slova a obraty původem ze staroslověnštiny, nejstaršího slovanského spisovného jazyka, dodávajícího ruské řeči nemalý díl starobylé vznešenosti.

Puškinova báseň ovšem zachycuje ještě jedno obecnější, velké téma. Od časů Lomonosovových byl ruský literární jazyk rozdělen s klasicistním zřetelem k čistotě formy do tří vzájemně neprostupných stylů. ${ }^{9}$ Estetické učení formulované Lomonosovem napří-

9 Tyto tř̌i styly odpovídaly různým literárním formám a žánrům: ke stylu „vysokému“ náležela heroická poema, óda a tragédie, $\mathrm{k}$,stř̌ednímu“ dramata, satiry, eklogy, korespondence mezi práteli a elegie a ke stylu „nízkému“ komedie, epigramy, písně a bajky. Každý z těchto stylů přitom mohl čerpat pouze $\mathrm{z}$ určitých vrstev ruské slovní zásoby. Výklad o tom je součástí Lomonosovova traktátu Předznamenání o užitku knih církevních v ruském jazyce, pocházejícího pravděpodobně z roku 1758 (Lomonosov 1952: 585-592, 891-892). 
klad nepřipouštělo, aby slova převzatá ze staroslověnštiny a patřící k „vysokému stylu“ byla kombinována se slovy běžně mluvené ruštiny, náležícími ke „stylu nízkému“. Puškin však svým obrazem „pravého básníka“, který se dává strhnout „tragickou lyrou Řecka“ a nepohrdá přitom „fraškou prostořekou“, Ossianem ani legendárním bohatýrem Ruslanem, naznačuje, že hranice žánrů a s nimi spojených vrstev jazyka mohou být i méně dogmatické, než jak kázala klasicistní estetika, a že literatura tím ve výsledku neztrácí, ale naopak mnohé získává. Pro úplnost dodejme, že svou tvorbou, v jejímž jazyce se múza „vážná“ často potkává s tou „nevážnou“, to Puškin nejenom naznačuje, ale sám také dokazuje. ${ }^{10}$

\section{Symbolika ruského hláskosloví}

Sledujeme-li, jaký význam přikládali ruští spisovatelé vlastní mateřštině, když formulovali své překladatelské úvahy, nemůže nám uniknout ještě jeden rozměr jejich výjimečného prožívání ruské řeči:

V jazyce ruském, podobá se, hojné opakování hlaholu písmene „a“ v představě vyvolávati může velikolepost, širokost prostoru, hlubokost a vysokost, jakož i nenadálý strach; časté užívání hlaholů písmen ,je“, „i“, „jat“, ,ju“ - laskavost, mazlivost, věci žalostné aneb nicotné; skrze „ja“ ukázati možno přívětivost, veselost, laskavost a zalíbení; skrze „o“, „u“, „y“ - věci strašlivé a mocné: hněv, závist, bázeň a tesknotu. (Lomonosov 1952: 241)

Takto vyložil jmenované i všechny další „hlaholy písmen“ neboli „hlásky“ ruské cyrilice ( $\mathrm{v}$ českém překladu pro zjednodušení nahrazené latinkou) polyhistor Lomonosov v roce 1748. Jeho hláskoslovná symbolika ovšem není čistě ruské specifikum. Český učenec Jan Amos Komenský (1592-1670) uvažoval velmi podobně, když formuloval kvality budoucího „jazyka obecného“, který měl podle jeho soudu nahradit jazykový babylon světa (Komenský 1920: 95-101): „Univerzální jazyk, který Komenský připravoval jako součást všenápravy, se měl co nejvíc přiblížit ideálnímu stavu, mimo jiné také psychologickou volbou prostředků. [...] Například ,k‘ značí podle Komenského něco ohromného, ,u'věc hrubou a nehybnou, popřípadě kulatou, takže ,ku' by mohlo znamenat Země“ (Marek 1970: 774). ${ }^{11}$

Dlužno podotknout, že Lomonosov sám připouštěl možnost i jiného než svého symbolického výkladu hlásek: „Kdokolivěk umí sluchem rozpoznávati, jak kteráž písmena zní, může hlaholy jejich upotřebiti dle uvážení svého, aniž by obzvláště pravidla tato

10 Novost, ba převratnost Puškinovy poezie můžeme doložit srovnáním se situací české kultury v době národního obrození, kdy se múza „vážná“ namnoze oddělila od té „nevážné", jak postřehl spisovatel Přemysl Rut: „Já nevím, jestli je to teorie správná, ale myslím si, že to nějak souvisí s poměrným mládím a nesamozrejmostí české kultury - s tím, že jsme si to během toho národního obrození jakoby znovu všechno vydupávali ze země a že jsme velmi chtěli, aby to mělo úroveň, a že si člověk tu úroveň nemůže zvolit. Ona se prostě dostavuje. A tady v ní byla určitá pochopitelná sice, ale přece jenom křečovitost - něco, co také tak zesílilo ten didaktický tón českého národního obrození" (Ryjáček 2012: rozhlasový pořad).

11 Marek dále zmiňuje mezinárodní vědeckou debatu o „fonologickém symbolismu“ a „psycholingvistice“, probíhající takřka po celé 20. století (Marek 1970: 774). 
př́sně dodržoval, nýbrž spíše jest třeba následovati myšlenky samé a snažiti se vyjádřiti je co možná jasně.“ (Lomonosov 1952: 242)

Je však pozoruhodné, jak se podobný př́stup $\mathrm{k}$ řeči, který nacházíme $\mathrm{v}$ Lomonosovově spisu z poloviny 18 . století, vrací v nových a nových obměnách v esejích a komentárích Vladimira Nabokova (1899-1977) - právě v souvislosti s uměleckým překladem:

Nedávno jsem zkoušel přeložit verše několika ruských básníků [...]. Mimo jiné jsem se musel popasovat s úvodním veršem jedné $\mathrm{z}$ nejkrásnějších Puškinových básní - Kouzelná chvíle, vzpomínám si...12 $\mathrm{V}$ ruštině ten verš zní přibližně takto: „Ja pómňu čúdnoje mgnavjéňje" (vzpomínám na kouzelný okamžik). [...] Hláskové skupiny čú a vjéň jsou v ruštině zvukově spjaté se slovy označujícími věci krásné a důležité a celý předchozí verš s okrouhlým a zlátnoucím slovem čúdnoje uprostřed a se vzájemně se vyvažujícími hláskami $m$ a $n$ po stranách zní ruskému uchu zároveň vzrušivě i konejšivě - tomuto paradoxu určitě porozumí každý umělec.

Když ale vezmete rusko-anglický slovník a vyhledáte si ona čtyři slova, vznikne vám prostoduchá a plytká fráze I remember a wonderful moment neboli pamatuji si úžasný okamžik. [...] Ja pómňu vyjadřuje hlubší a plynulejší ponor do minulosti než I remember, které se jako nezkušený potápěč nejprve jen rozplácne břichem o hladinu. Ve slově čúdnoje se zase ozývá pohádkové čud’neboli příšera, šeptem vyslovené staroruské ču neboli poslyš, dativní zakončení slova luč, označujícího paprsek, a mnoho dalších pěkných asociací. Svým zněním i duši se to Puškinem použité slovo zkrátka váže k určité slovní řadě, přičemž ruská slovní řada neodpovídá té anglické, spjaté s obratem I remember. A naopak anglické remember, které nejde dohromady s příslušnou slovní řadou ruského pómňu, se pojí s určitou řadou slov anglických, je-li použito skutečným básníkem. (Nabokov 1941: nestránkováno)

Nabokov rozvíjí zvukově asociační přístup k jazyku, který Lomonosov ve svém zamyšlení nad ruským hláskoslovím pouze heslovitě načrtnul, do velejemných nuancí. Současně ale dochází k vlastní překladové teorii „slovních řad“, k nimž se v různých jazycích vážou různá slova, a poukazuje tak na limity každého pokusu o převedení poezie do jiné řeči. Dokonce se zdá, že možnost takového převedení přímo popírá, jak vyplývá i z prvního čtyřverší jeho dvou oněginských strof ${ }^{13}$ (Nabokov 1955: 34), napsaných v době, kdy sám pracoval na anglickém překladu Puškinova Evžena Oněgina:

Co je to překlad? Na podnose

hlava utatá básníku,

papouščí skřek, vřesk opic - prostě

zlý výsměch mrtvým klasikům.

Ty červy, kterés tepal rýmy,

Bůh zprostí vin, když odpustíš mi

mou taktiku, ó Puškine.

Stvol tvého verše vedl mne

až dolů ke kořenům. $Z$ těch

12 V překladu Emanuela Frynty (Puškin 1975: 62).

13 Oněginskou strofou je psán téměř celý Puškinův Evžen Oněgin. Nabokov svou básní ilustruje metrum i rýmové schéma oněginské strofy, založené na formě sonetu. Český překlad činí totéž s výjimkou pravidelného střídání mužských a ženských rýmů. 
dal jsem pak vyrůst v cizí zemi

novému stvolu, když jsem měnil

v prózu tvůj román v sonetech -

je plná trnů, ale může

být proto př́buznou tvé růže.

Odrazy slov se pouze chvějí

jak zvlněný svit luceren

$\mathrm{v}$ zrcadle řeky, než se jejich

město $\mathrm{z}$ mlh noci probere.

Puškine, unikáš mi! Zase

s Evženem kdesi na cestách jsem,

zas Tatáninu náušnici

do rukou beru, ve slovnících

přehmaty druhých zkoumám - a s tou

omamnou hudbou čtvrté sloky

osmého zpěvu trávím roky.

Jsem básníkem i scholiastou.

Výsledek mého podniku?

Ptačí trus na tvém pomníku. ${ }^{14}$

Za jediný překlad „v pravém slova smyslu“ považuje Nabokov „překlad doslovný“, který „,zachycuje (nakolik to asociativní a syntaktické možnosti jazyka překladu dovolují) přesný kontextuální význam originálu“. Jakýkoliv jiný typ převedení rýmované básně do jiného jazyka je bud” „překladem opisným“, nebo „lexikálním“, které Nabokov odsuzuje jako „obyčejnou imitaci“ (Nabokov 1964: 7f-8f). Připomínají mu, jak se praví v předchozích verších, „utatou hlavu básníka“, přinášenou čtenárům poezie „na podnose“ - na způsob hlavy novozákonního proroka Jana Křtitele, kterou si od prorokova věznitele jako odměnu za svůj tanec vyžádala biblická dívka zvaná Salomé.

Nabokov dále konstatuje, že doslovné převedení Evžena Oněgina do cizího jazyka se vylučuje se zachováním jeho rýmové struktury, nebot „reprodukovat rýmy a zároveň přeložit celou Puškinovu báseň doslova se matematicky vylučuje“ (Nabokov 1964: 9f). A třebaže připouští, že „ztrátou rýmů báseň přijde o své kvítky, které žádné vysvětlivky ani kouzla kritických komentárů nenahradi“ (Nabokov 1964: 9f), rozhodl se Puškinův veršovaný román převést „doslova“, přesněji (s několika výjimkami) jambicky rytmizovanou prózou (Nabokov 1964: 10f). Svůj překlad přitom doprovodil několikasetstránkovým komentářem, upozorňujícím anglojazyčné čtenáře na vše, co by jim v pouhém překladu mohlo uniknout.

Součástí nejrozsáhlejšího z oněginovských komentářủ je téměř každý významový i formální detail Puškinova originálu, včetně podrobného rozboru „omamné hudby čtvrté sloky osmého zpěvu“, která Nabokova fascinovala svou hláskovou instrumentací (Pushkin 1964: 148-149). Snad jen Tatániny zlaté „náušnice“, zmíněné (v jednotném čísle) v citované nápodobě oněginské strofy, Nabokovově drobnohledu unikly, třebaže se o nich Puškin (ve čtrnácté sloce páté kapitoly Oněgina) výslovně zmiňuje.

14 Překlad posledního verše vychází z pozdější varianty publikované v knize Poems and Problems (Nabokov 1969: 175), nebot první verze vyznívá uhlazeněji a méně sebeironicky: „Výsledek mého podniku? / Pouhý stín tvého pomníku“ (Nabokov 1955: 34). 


\section{Básnickost ruské duše}

Všechny představené texty, věnované nepřímo (v případě Lomonosova) i přímo (u Puškina a Nabokova) umění překladu, dokládají vyznavačsky silný vztah jejich autorů $\mathrm{k}$ rodné řeči. Viděli jsme, že tento vztah je nesen nebývalým jazykovým sebevědomím, daným rozlehlostí ruské ř́še i přesvědčením o výjimečných kvalitách ruštiny v porovnání s jinými evropskými jazyky. Byli jsme svědky toho, jak slovo ruského překladu Homérova eposu znělo prvnímu básníkovi Ruska prorocky a nově. A v neposlední řadě jsme sledovali, s jakým smyslem pro detail se ruští literární klasikové dovedli zaposlouchávat do zvuků ruských hlásek, naplněných (v jejich uších) zvláštní symbolikou.

Proč se však vědec Lomonosov tak „nevědecky“ vyznává ze své víry v mateřštinu? Proč Puškin vítá Gnědičův překlad Iliady tím, že napíše vlastní verše, spějící nejen k oslavě jednoho mimořádně zdařilého překladatelského činu, ale hlavně $\mathrm{k}$ obrazu „pravého básníka“? Z jakého důvodu Nabokov, zastánce doslovného, a proto nerýmovaného překladu veršů, reflektuje svoji mnohaletou práci na anglickém překladu Evžena Oněgina dvěma rýmovanými oněginskými strofami? A konečně: proč všechny ty rozbory symboliky ruského hláskosloví, které Lomonosov započal a Nabokov rozvíjel do velejemných významových záchvěvư?

Protože všichni jmenovaní promlouvají především jako básníci. Byl to v první řadě básnický vztah $\mathrm{k}$ rodné řeči, který určoval jejich pojetí uměleckého překladatelství a v hlubším smyslu spoluutvářel i "ruskost“ jejich „duše“. Pokud totiž vyjdeme z teze formulované spisovatelem Karlem Čapkem, že národnost není dána „rasou“, „dějinami“, „společným osudem“ ani žádným „národním programem“, nýbrž právě a jedině „řečí", která „duši“ jednoho národa odlišuje „ode všech jiných na světě“" (Čapek 1984: 184-185), pak jedním z nezaměnitelných rozměrů každé národnosti je rovněž povaha vztahu k vlastní mateřštině.

\section{BIBLIOGRAFIE}

Baer, Brian James - Olshanskaya, Natalia (eds.) (2013) Russian Writers on Translation, Manchester: St. Jerome Publishing.

Belinskij, Vissarion Grigorjevič (1960) 'Russkaja literatura v 1841 godu', in Andrej Venediktovič Fjodorov - Jurij Davidovič Levin (eds.) Russkije pisateli o perevode, Leningrad: Sovetskij pisatel, 223-225.

Bucher, Gérard (2004) 'Rilke's Poetry in the French Language: The Enigma of Mythopoietic Reversal', in Erika A. Metzger - Michael M. Metzger (eds.) A Companion to the Works of Rainer Maria Rilke, Rochester (NY), USA/Woodbridge, UK: Camden House, 236-261.

Cvetajeva, Marina (1995) 'R.-M. Rilke, 6 ijulja 1926', in Marina Cvetajeva, Sobranije sočinenij v semi tomach, tom 7, Moskva: Ellis Lak, 66-68.

Čapek, Karel (1984) 'Marsyas', in Karel Čapek, Spisy, svazek XIII, Praha: Československý spisovatel, $7-188$.

Deržavin, Gavrila Romanovič (1872) 'Rassuždenije o liričeskoj poezii', in Gavrila Romanovič Deržavin Sočinenija v proze, tom 7, Sankt-Peterburg: izdatelstvo Imperatorskoj Akademii Nauk, 516-628.

Fjodorov, Andrej Venediktovič - Levin, Jurij Davidovič (eds.) (1960) Russkije pisateli o perevode, Leningrad: Sovetskij pisatel.

Fjodorov, Andrej Venediktovič (1960) 'Russkije pisateli i problemy perevoda', in Andrej Venediktovič Fjodorov - Jurij Davidovič Levin (eds.) Russkije pisateli o perevode, Leningrad: Sovetskij pisatel, 6f-27f. 
Gogol, Nikolaj Vasiljevič (1952) 'Ob Odisseje, perevodimoj Žukovskim: (Pismo k N. M. J. ...vu)', in Nikolaj Vasiljevič Gogol, Polnoje sobranije sočinenij, tom 8, Moskva/Leningrad: Izdatelstvo Akademii Nauk SSSR, 236-244.

Komenský, Jan Amos (1920) Cesta světla, Praha: Alois Svoboda.

Lomonosov, Michail Vasiljevič (1952) 'Predislovije o polze knig cerkovnych v rossijskom jazyke', in Michail Vasiljevič Lomonosov, Polnoje sobranije sočinenij, tom 7, Moskva/Leningrad: Akademija Nauk SSSR, 585-592.

Michail Vasiljevič Lomonosov (1952) 'Rossijskaja grammatika', in Polnoje sobranije sočinenij, tom 7, Moskva/Leningrad: Izdatelstvo Akademii nauk SSSR, 389-578.

Marek, František (1970) 'Komenský a cizí jazyky', Pedagogika (5), 771-783.

Nabokov, Vladimir (1964) 'Foreword', in Aleksandr Pushkin, Eugene Onegin (translated by Vladimir Nabokov), Vol. 1, New York: Bollingen Foundation, $7 \mathrm{f}-12 \mathrm{f}$.

Nabokov, Vladimir (1955) 'On Translating "Eugene Onegin”', The New Yorker, January 8, 34.

Nabokov, Vladimir (1969) 'On Translating "Eugene Onegin”, in Vladimir Nabokov, Poems and Problems, New York: McGraw-Hill, 175.

Nabokov, Vladimir (1941) 'The Art of Translation', The New Republic, August 4, 160-162.

Pushkin, Aleksandr (1964) Eugene Onegin (translated by Vladimir Nabokov), Vol. 3, New York: Bollingen Foundation.

Puškin, Aleksandr Sergejevič (1995) 'Gnediču', in Aleksandr Sergejevič Puškin, Sobranije sočinenij v pjati tomach, tom 1, Sankt-Peterburg: Bibliopolis, 481.

Puškin, Aleksandr Sergejevič (1960) 'Iliada Gomerova, perevedennaja N. Gnedičem, členom imperatorskoj Rossijskoj akademii i pr., in Andrej Venediktovič Fjodorov - Jurij Davidovič Levin (eds.), Russkije pisateli o perevode, Leningrad: Sovetskij pisatel, 159-160.

Puškin, Aleksandr Sergejevič (1975) 'A. P. Kernové, in Alexandr Sergejevič Puškin, V bouři zrál můj hlas, Praha: Mladá fronta, 62.

Puškin, Aleksandr Sergejevič (1954) 'O predislovii g-na Lemonte k perevodu basen I. A. Krylova', in Boris Viktorovič Tomaševskij - Jurij Davidovič Levin (eds.), Russkije pisateli o jazyke, Leningrad: Sovetskij pisatel, 74-75.

Rubáš, Stanislav - Rosová, Anna (eds.) Rusko v zrcadle překladu (eseje, verše, dopisy a rozhovory), Praha: Karolinum (v tisku).

Ryjáček, Pavel (2012) 'Telefonotéka' (pořad Českého rozhlasu Vltava): http://prehravac.rozhlas.cz/audio /2549643 (access: 18. 6. 2019).

\section{PEЗЮME}

В настоящей статье дан анализ канонических текстов Михаила В. Ломоносова (1711-1765), Александра С. Пушкина (1799-1837) и Владимира Набокова (1899-1977), посвященных искусству художественного перевода. Подобранные трактаты и стихи свидетельствуют прежде всего об исключительном отношении русских писателей к родному языку и классической поэзии, способной отражать высший уровень народного языка. Данное отношение отличается небывалой «языковой самоуверенностью», основанной на статусе России как великой державы и на убеждении русских писателей в беспримерных качествах родного языка в сопоставлении с другими языками Европы. Более того, в наблюдениях и комментариях русских писателей по поводу искусства перевода четко сказывается их поэтическая муза, одна из стержневых черт русского народного менталитета.

PhDr. Stanislav Rubáš, Ph.D. Ústav translatologie, Filozofická fakulta, Univerzita Karlova stanislav.rubas@ff.cuni.cz 